\section{Case Reports in Neurology}

Case Rep Neurol 2021;13:218-224

DOI: $10.1159 / 000514242$

Published online: April 6, 2021

(C) 2021 The Author(s)

Published by S. Karger AG, Basel

www.karger.com/crn

This article is licensed under the Creative Commons Attribution-NonCommercial 4.0 International License (CC BY-NC) (http://www.karger.com/Services/OpenAccessLicense).

Usage and distribution for commercial purposes requires written permission.

\title{
Two Similar Cases of a Misdiagnosed Anterior Communicating Aneurysm Rupture
}

\author{
Jaromir Hanuska Jan Klener \\ Department of Neurosurgery, Na Homolce Hospital, Prague, Czech Republic
}

\section{Keywords}

Cerebral aneurysm $\cdot$ Clipping $\cdot$ Intracerebral hemorrhage

\begin{abstract}
The misdiagnosis of a ruptured aneurysm directly endangers patient's life and health due to the high risk of rebleeding and its sequelae. In this paper, we present two uncommon cases of anterior communicating artery aneurysm rupture with a relatively small intracerebral bleeding, seemingly without a diffuse subarachnoid hemorrhage $(\mathrm{SAH})$, and a relatively mild clinical presentation. In these cases, the initial diagnosis failed, leading to missed aneurysmal ruptures. The atypical or mild clinical presentation, and the absence of SAH on computed tomography (CT) and/or magnetic resonance imaging (MRI) scan or absent blood in the cerebrospinal fluid (CSF) are all factors which could lead to a false or delayed diagnosis. Meticulous evaluation of patient's symptoms, CT, MRI scans, and CSF findings are mandatory. The possibility of a small blood clot without a diffuse SAH must be considered.

(c) 2021 The Author(s) Published by S. Karger AG, Basel
\end{abstract}

\section{Introduction}

Intracranial aneurysm is a relatively common lesion with a prevalence of $1-5 \%$ in the adult population [1-3]. About 20-50\% of all aneurysm ruptures during a person's lifetime can typically lead to a subarachnoid hemorrhage (SAH) [4].

\begin{tabular}{l}
\hline \\
Jargeromir Hanuska \\
Department of Neurosurgery, Na Homolce Hospital \\
Roentgenova $37 / 2$ \\
CZ-15000 Prague 5 (Czech Republic) \\
jaromir.hanuska@gmail.com
\end{tabular}




\section{Case Reports in Neurology}

Case Rep Neurol 2021;13:218-224

DOI: $10.1159 / 000514242$

(c) 2021 The Author(s). Published by S. Karger AG, Basel www.karger.com/crn

Hanuska and Klener: Two Similar Cases of a Misdiagnosed Anterior Communicating Aneurysm Rupture

SAH typically manifests as a sudden severe headache, with meningeal irritation signs, neurological deficit, or as an immediate cause of coma, which is related to a poor outcome [5]. The Hunt-Hess Scale $(\mathrm{H}-\mathrm{H})$ is a clinical grading scale which describes a clinical condition on admission and is a good predictor of the ultimate outcome [4, 6]. SAH could also be classified with the WFNS (World Federation of Neurosurgical Societies) scale which reflects the patient's Glasgow Comma Scale and motor deficit [7]. The initial diagnostic test for SAH is a computed tomography (CT) scan. If the CT scan does not show any evidence of SAH, a lumbar puncture may detect it with higher sensitivity [2]. On a magnetic resonance imaging (MRI) scan, the SAH is clearly detected on fluid-attenuated inversion recovery (FLAIR) images within 2 days of the SAH onset with sensitivity and specificity reaching $100 \%$, which is better than the CT [8, 9]. CT angiography, MRI angiography, or the digital subtraction angiography are then performed in order to visualize the source of bleeding, most frequently a ruptured aneurysm. If the aneurysm rupture is confirmed, the lesion is then secured by the microsurgical clipping or the endovascular occlusion to avoid rebleeding and enable an aggressive treatment of the vasospasm [2].

However, in some cases of aneurysmal rupture, a diffuse SAH does not have to be present. The incidence of aneurysmal rupture with an intraparenchymal hemorrhage and/or intraventricular hemorrhage without a SAH is 1.6\% [10]. The absence of SAH could then pose some risk for misdiagnosis.

In this paper, we present two uncommon cases of intracranial anterior communicating artery (ACom) aneurysm rupture with a relatively small intracerebral bleeding seemingly without a diffuse SAH and with a relatively mild clinical presentation where the initial diagnosis failed and the aneurysmal rupture was therefore missed.

\section{Case Presentation}

\section{Case 1}

A 40-year-old male with a sudden onset of a severe headache and meningism after standing up from a chair was transferred immediately to a regional neurology department. Initial diagnosis of a cervical spine pain was established. After 3 days of analgesic treatment, he was readmitted due to the persistent headache, low grade fever, visual impairment, photophobia, and spastic paraparesis. One week after the onset of symptoms, a CT and MRI were performed. A multilocular lesion was found in the fronto-mesial region and interpreted as an infection or a tumor (a hyperdensity in a T1 and T2, with no enhancement after contrast application) (Fig. 1a). No signs of a diffuse SAH were detected. There was neither an elevation of the C-reactive protein $(3.1 \mathrm{mg} / \mathrm{L})$ nor an increased white blood cell count $\left(8.9 \times 10^{9} / \mathrm{L}\right)$. CSF sampling from the lumbar puncture was interpreted as a suspected serous meningitis (CSF-WBC 103/ $\mu \mathrm{L}$; CSF-CB $0.77 \mathrm{~g} / \mathrm{L}$; CSF-glu $3.24 \mathrm{mmol} / \mathrm{L})$ with elevated number of erythrocytes $(129 / \mu \mathrm{L})$. The consulting neurosurgeon from a different department accepted the suspicion of a neuroinfection. The antibiotic therapy was started (ceftriaxone for 6 days) for a suspected neuroinfection. Later on, an EEG examination was normal, and a follow-up MRI scan (11 days later) showed a partial regression of these lesions. The clinical status of the patient remained unchanged.

Six months later, the patient was seen in our department for the first time. Our review of the MRI scans raised a suspicion of a small intracerebral clot from an ACom aneurysm rupture, and we recommended a CT angiography which showed a small ACom aneurysm (Fig. 1b). The

\section{Karger'=}




\section{Case Reports in Neurology}

Case Rep Neurol 2021;13:218-224

DOI: $10.1159 / 000514242$

(c) 2021 The Author(s). Published by S. Karger AG, Basel www.karger.com/crn

Hanuska and Klener: Two Similar Cases of a Misdiagnosed Anterior Communicating Aneurysm Rupture

patient was admitted and a microsurgical treatment was performed - an antegrade fenestrated tube by two fenestrated clips was created across an ipsilateral-left-A2. The perioperative and postoperative periods were uneventful and the patient was discharged 7 days after the surgery with no neurological deficit. The postoperative CT angiography showed a complete closure of the aneurysm (Fig. 1c). On the last follow-up, 23 months after the surgery, the patient was neurologically intact.

\section{Case 2}

A 51-year-old male presented with a several week history of a gradually progressing headache in different locations (mainly the occipital and the frontal regions), a feeling of pressure behind his eyes, and with an organic psychosyndrome. The symptoms were initially unsuccessfully treated by a neurologist as a cervicocranial syndrome. One week later, the patient underwent a cranial CT and MRI scans, and an expansive lesion in the rostrum of the corpus callosum was described. A lymphoma or a high-grade glioma was suspected (high T2 signal, higher T1 signal, slight contrast enhancement, slight diffusion restriction) (Fig. 2a). After several days of corticosteroid treatment by a local neurologist, the symptoms improved significantly, limited to a mild headache and a slight organic psychosyndrome.

We saw the patient for the first time 2 weeks after the described events due to a persistent headache and apathy. The scans were reviewed and like in the first case, there was a suspicion of a small subacute intracerebral hemorrhage from an ACom aneurysm rupture. Cerebral angiography was performed and confirmed the ACom aneurysm (Fig. 2b). A microsurgical treatment was indicated and the aneurysm was clipped by a single clip. The perioperative and postoperative periods were without any complications.

Eight days after the surgery, the CT angiography confirmed a complete closure of the aneurysm (Fig. 2c). On the last follow-up, 5 months after the surgery, the patient was without any neurological deficit.

\section{Discussion}

Intracerebral aneurysm rupture leads to death in $45 \%$ of cases, with rebleeding and delayed ischemic deficit being the major causes of permanent disability. Correct initial diagnosis is crucial for the patient's outcome [11]. Misdiagnosis is present in 12-51\% of cases [11-18], and rebleeding occurs in 26-73\% of misdiagnosed cases [19-21]. The diagnostic failures are often related to patients with a good neurological grade (H-H I-II) [11, 22]. Their clinical signs are interpreted as cervicobrachial syndrome and migraine (36\%), viral syndrome $(11 \%)$ or the diagnosis is not established $(12 \%)[11,12]$. Misdiagnosed patients (H-H I-II) are more likely to die or be severely disabled (36\%) compared to the correctly diagnosed patients $(13 \%)[11,18]$. The frontline physicians play the key diagnostic role, especially the emergency room physicians (43\%) [11]. Previous studies showed that the most common diagnostic failures are incorrect interpretation of the initial CT scans and inaccurate CSF findings $[11,12$, 22]. Immediate CT without contrast is the most sensitive imaging in SAH. After $6 \mathrm{~h}$ of headache onset, CT has nearly $100 \%$ sensitivity and specificity, after $24 \mathrm{~h}$, it is $93 \%$, after 3 days, $80 \%$ and after 1 week, the sensitivity decreases to 50\% [23]. Not only delay could be the cause of a negative CT, but a very small initial volume of hemorrhage or a low hematocrit could be the reason of misdiagnosis $[11,24]$. Xantochromy in CSF, detected by spectrophotometry,

\section{Karger'"}




\section{Case Reports in Neurology}

Case Rep Neurol 2021;13:218-224

DOI: $10.1159 / 000514242$

(c) 2021 The Author(s). Published by S. Karger AG, Basel www.karger.com/crn

Hanuska and Klener: Two Similar Cases of a Misdiagnosed Anterior Communicating Aneurysm Rupture

develops between 2 and $12 \mathrm{~h}$ after bleeding and takes at least 2 weeks. This finding is pathognomic for SAH and is important if the initial CT scan is negative [25].

In our first case, the clinical manifestation was quite typical of an aneurysm rupture (i.e., sudden onset of headache, neck stiffness), and neither a CT nor a lumbar puncture was performed in the acute stage. However, further mistakes followed - a bad evaluation of the clinical status evolution (possible ACA vasospasm symptoms), an incorrect CT, MR and CSF finding interpretation. The location of the mass lesion on CT and MRI - consistent with a subacute blood clot - seen in the vicinity of the ACom complex should have implied a possible ACom rupture. The CSF finding was not specific for an ongoing neuroinfection, hence the antibiotic therapy was unjustified. A low-grade or frank fever are common signs in patients with intracerebral hemorrhage and are not necessarily associated with an infection [26]. Interestingly, there were no signs of a diffuse SAH on the CT which may have been caused by the delayed time of the CT scan (more than $24 \mathrm{~h}$ ) [27]. Moreover, the CT scan is not $100 \%$ sensitive to SAH.

In our second case, the clinical presentation was not typical for SAH - no sudden headache or meningism was present. However, as in the previous case, the location of the lesion, and the signal characteristics of the CT and MRI scans should have raised a suspicion of a subacute intracerebral hematoma due to an ACom aneurysm rupture. The delay of the CT scanning was again an important factor for the misinterpretation. The hematomas were located in the fronto-mesial region in the proximity of the ACom, therefore, an angiography or a CT angiography should have been indicated immediately. Moreover, the aneurysm itself was identifiable on the MRI.

Both our case reports represent a misdiagnosis of a ruptured aneurysm. They have some common features: (1) the clinical presentation was mild or atypical for SAH; (2) the aneurysm rupture caused only a small intracerebral hematoma, possibly without a diffuse $\mathrm{SAH}$; (3) delayed CT, CSF and MR examinations; (4) incorrect interpretation of a performed CT, MR and CSF.

Fortunately, both patients had not experienced rebleeding and their aneurysms were successfully treated by microsurgery, albeit in a delayed fashion.

In conclusion, misdiagnosis of ruptured aneurysms directly endangers the patient's life and health due to the high risk of rebleeding and its sequelae. The atypical or mild clinical presentation and the absence of a diffuse SAH on the CT and/or MR scan, or in CSF, are factors which could lead to a false or delayed diagnosis. We would also like to highlight that beside the careful attention to the typical SAH symptoms and signs, CT imaging should be used to exclude SAH for any patient with mild symptoms in whom the possible SAH is considered [11]. Meticulous evaluation of the patient's symptoms, the CT and MR scans and the CSF findings is crucial. The possibility of a small blood clot without a diffuse SAH must be considered.

\section{Statement of Ethics}

This work follows the guidelines for human studies and was conducted ethically in accordance with the World Medical Association Declaration of Helsinki. Written informed consent was obtained from the patients for publication of this case report and any accompanying images.

\section{Karger'=}




\section{Case Reports in Neurology}

\begin{tabular}{l|l}
\hline Case Rep Neurol 2021;13:218-224 \\
\hline DOI: 10.1159/000514242 & $\begin{array}{l}\text { ( ) 2021 The Author(s). Published by S. Karger AG, Basel } \\
\text { www.karger.com/crn }\end{array}$ \\
\hline
\end{tabular}

Hanuska and Klener: Two Similar Cases of a Misdiagnosed Anterior Communicating Aneurysm Rupture

\section{Conflict of Interest Statement}

The authors have no conflicts of interest to declare.

\section{Funding Sources}

No funding was received.

\section{Author Contributions}

J.H. analyzed both cases and wrote the paper. J.K. performed the surgical treatment, participated in writing the paper and most of its editing.

\section{References}

1 Wiebers DO, Whisnant JP, Huston J 3rd, Meissner I, Brown RD Jr, Piepgras DG, et al.; International Study of Unruptured Intracranial Aneurysms Investigators. Unruptured intracranial aneurysms: natural history, clinical outcome, and risks of surgical and endovascular treatment. Lancet. 2003 Jul;362(9378):103-10.

2 Brisman JL, Song JK, Newell DW. Cerebral aneurysms. N Engl J Med. 2006 Aug;355(9):928-39.

3 Schievink WI. Intracranial aneurysms. N Engl J Med. 1997 Jan;336(1):28-40.

4 Le Roux PD, Winn HR, Newell DW, editors. Management of cerebral aneurysms. Philadelphia: Saunders; 2004.

5 Wijdicks EF, Kallmes DF, Manno EM, Fulgham JR, Piepgras DG. Subarachnoid hemorrhage: neurointensive care and aneurysm repair. Mayo Clin Proc. 2005 Apr;80(4):550-9.

6 Hunt WE, Hess RM. Surgical risk as related to time of intervention in the repair of intracranial an eurysms. Neurosurg. 1968 Jan;28(1):14-20.

7 Teasdale GM, Drake CG, Hunt W, Kassell N, Sano K, Pertuiset B, et al. A universal subarachnoid hemorrhage scale: report of a committee of the World Federation of Neurosurgical Societies. J Neurol Neurosurg Psychiatry. 1988 Nov;51(11):1457.

8 Noguchi K, Ogawa T, Inugami A, Toyoshima H, Sugawara S, Hatazawa J, et al. Acute subarachnoid hemorrhage: MR imaging with fluid-attenuated inversion recovery pulse sequences. Radiology. 1995 Sep;196(3):773-7.

9 Nelson SE, Sair HI, Stevens RD. Magnetic Resonance Imaging in Aneurysmal Subarachnoid Hemorrhage: Current Evidence and Future Directions. Neurocrit Care. 2018 0ct;29(2):241-52.

10 Thai QA, Raza SM, Pradilla G, Tamargo RJ. Aneurysmal rupture without subarachnoid hemorrhage: case series and literature review. Neurosurgery. 2005 Aug;57(2):225-9.

11 Kowalski RG, Claassen J, Kreiter KT, Bates JE, Ostapkovich ND, Connolly ES, et al. Initial misdiagnosis and outcome after subarachnoid hemorrhage. JAMA. 2004 Feb;291(7):866-9.

12 Adams HP Jr, Jergenson DD, Kassell NF, Sahs AL. Pitfalls in the recognition of subarachnoid hemorrhage. JAMA. 1980 Aug;244(8):794-6.

13 Vannemreddy P, Nanda A, Kelley R, Baskaya MK. Delayed diagnosis of intracranial aneurysms: confounding factors in clinical presentation and the influence of misdiagnosis on outcome. South Med J. 2001 Nov;94(11):1108-11.

14 Chan BS, Dorsch NW. Delayed diagnosis in subarachnoid haemorrhage. Med J Aust. 1991 Apr;154(8):50911.

15 Kassell NF, Kongable GL, Torner JC, Adams HP Jr, Mazuz H. Delay in referral of patients with ruptured aneurysms to neurosurgical attention. Stroke. 1985 Jul-Aug;16(4):587-90.

16 Schievink WI, van der Werf DJ, Hageman LM, Dreissen JJ. Referral pattern of patients with aneurysmal subarachnoid hemorrhage. Surg Neurol. 1988 May;29(5):367-71.

17 Neil-Dwyer G, Lang D. 'Brain attack' — aneurysmal subarachnoid haemorrhage: death due to delayed diagnosis. J R Coll Physicians Lond. 1997 Jan-Feb;31(1):49-52. 


\section{Case Reports in Neurology}

\begin{tabular}{l|l}
\hline Case Rep Neurol 2021;13:218-224 \\
\hline DOI: 10.1159/000514242 & $\begin{array}{l}\text { @ 2021 The Author(s). Published by S. Karger AG, Basel } \\
\text { www.karger.com/crn }\end{array}$ \\
\hline
\end{tabular}

Hanuska and Klener: Two Similar Cases of a Misdiagnosed Anterior Communicating Aneurysm Rupture

18 Ois A, Vivas E, Figueras-Aguirre G, Guimaraens L, Cuadrado-Godia E, Avellaneda C, et al. Misdiagnosis Worsens Prognosis in Subarachnoid Hemorrhage With Good Hunt and Hess Score. Stroke. 2019 Nov;50(11):3072-6.

19 Mayberg MR, Batjer HH, Dacey R, Diringer M, Haley EC, Heros RC, et al. Guidelines for the management of aneurysmal subarachnoid hemorrhage. A statement for healthcare professionals from a special writing group of the Stroke Council, American Heart Association. Circulation. 1994 Nov;90(5):2592-605.

20 van Gijn J, Rinkel GJ. Subarachnoid haemorrhage: diagnosis, causes and management. Brain. 2001 Feb;124(Pt 2):249-78.

21 Barber TR, Lawton M, Rolinski M, Evetts S, Baig F, Ruffmann C, et al. Prodromal Parkinsonism and Neurodegenerative Risk Stratification in REM Sleep Behavior Disorder. Sleep. 2017 Aug; 40(8). DOI: https://doi.org/10.1093/sleep/zsx071.

22 Mayer PL, Awad IA, Todor R, Harbaugh K, Varnavas G, Lansen TA, et al. Misdiagnosis of symptomatic cerebral aneurysm. Prevalence and correlation with outcome at four institutions. Stroke. 1996 Sep;27(9):1558-63.

23 Perry JJ, Stiell IG, Sivilotti MLA, Bullard MJ, Emond M, Symington C, et al. Sensitivity of computed tomography performed within six hours of onset of headache for diagnosis of subarachnoid haemorrhage: prospective cohort study. BMJ. 2011 Jul;343:d4277. https://doi.org/10.1136/bmj.d4277.

24 Edlow JA, Malek AM, Ogilvy CS. Aneurysmal subarachnoid hemorrhage: update for emergency physicians. Emerg Med. 2008 Apr;34(3):237-51.

25 Ferro JM, Canhão P, Peralta R. Update on subarachnoid haemorrhage. J Neurol. 2008 Apr;255(4):465-79.

26 Gillow SJ, Ouyang B, Lee VH, John S. Factors Associated with Fever in Intracerebral Hemorrhage. J Stroke Cerebrovasc Dis. 2017 Jun;26(6):1204-8.

27 Tong DM, Zhou YT. Predictors of the subarachnoid hemorrhage of a negative CT scan. Stroke. 2010 Oct;41(10):e566-7.
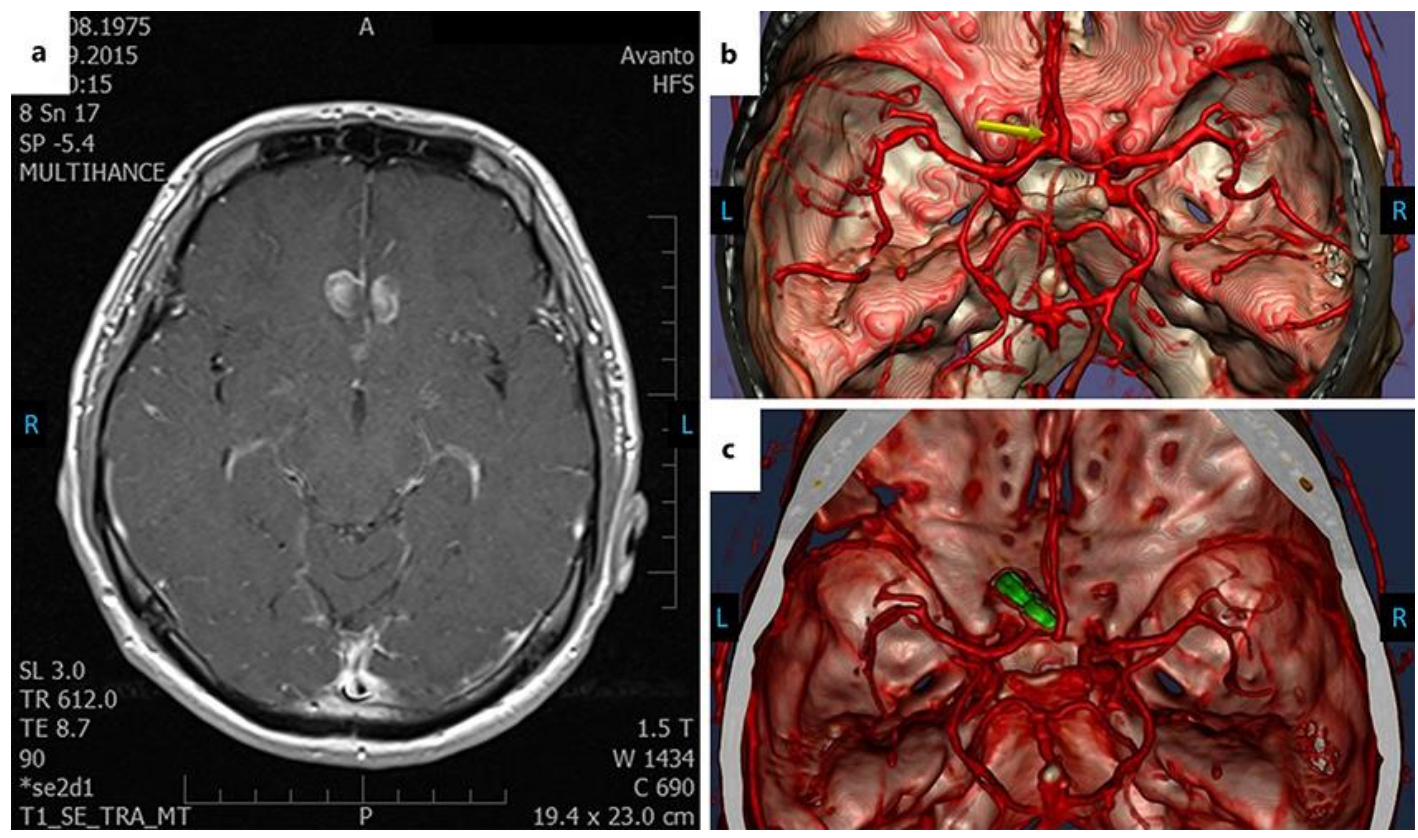

Fig. 1. MR and CT angiography scans of case 1. a MR (T1-weighted images with gadolinium contrast in axial cut) showing two hyperintense intraparenchymal lesions in the fronto-mesial region. $\mathbf{b}$ CT angiography (3D reconstruction) showing an aneurysm of ACom (yellow arrow). c Postoperative CT angiography (3D reconstruction) with successfully closed aneurysm ACom (clip - green). L, left side; R, right side. 


\section{Case Reports in Neurology}

\begin{tabular}{l|l}
\hline Case Rep Neurol 2021;13:218-224 \\
\hline DOI: 10.1159/000514242 & $\begin{array}{l}\text { C 2 2021 The Author(s). Published by S. Karger AG, Basel } \\
\text { www.karger.com/crn }\end{array}$ \\
\hline
\end{tabular}

Hanuska and Klener: Two Similar Cases of a Misdiagnosed Anterior Communicating Aneurysm Rupture
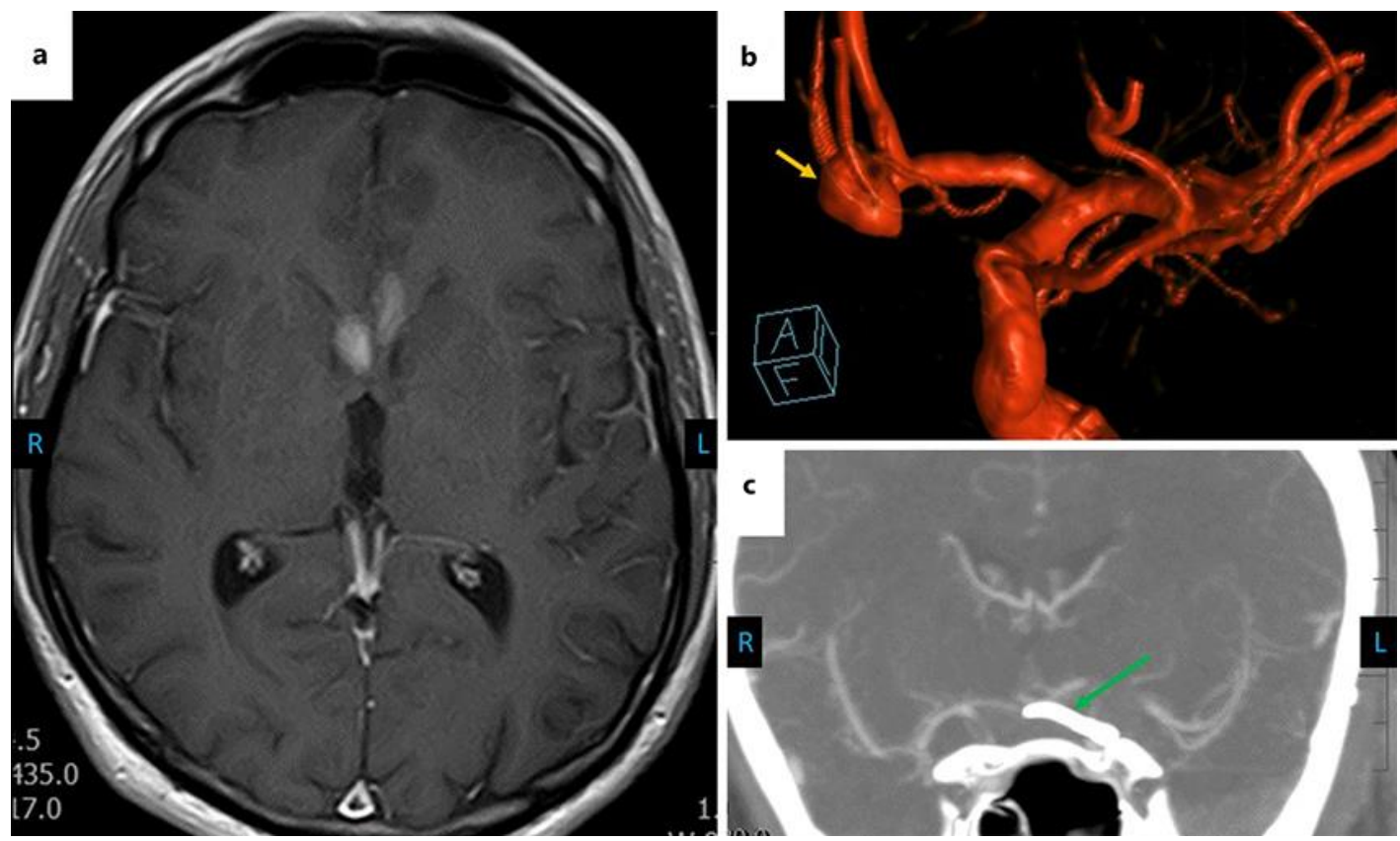

Fig. 2. MR and CT angiography scans of case 2. a MR (T1-weighted images with gadolinium contrast in axial cut) showing two hyperintense intraparenchymal lesions in the fronto-mesial region. $\mathbf{b}$ Angiography (3D reconstruction) showing an aneurysm of ACom (yellow arrow). c Postoperative CT angiography (coronary cut) with successfully closed aneurysm ACom (clip - green arrow). L, left side; R, right side. 